\title{
Learning Fun English Using Total Physical Response Method
}

\author{
Zulia Karini \\ Informatics Study Program, Universitas AMIKOM Purwokerto, Indonesia \\ zulia@amikompurwokerto.ac.id
}

\begin{abstract}
ABSTRAK
\section{Keywords:}

English,

Fun,

Total Physical Response,

Taman Baca Kudi.

One of the difficult parts of learning the target language for English language learners is the acquisition of vocabulary. Most learners find that English is a hard subject to be studied. However, they can enjoy learning English when it is taught in a fun way. Using games for teaching vocabulary has been very popular for several decades. Different studies revealed that games are beneficial in vocabulary learning because they enhance students' ability to memorize words, encourage student's interaction, improve their communicative skills and enhance students' motivation. Games also can help the teachers to create contexts in which the language is useful and meaningful. Watching a movie is also a great way to learn English. Learners can improve their vocabulary while watching a film. Total Physical Response method can also be applied when teaching English for children. This method makes language skills more quickly understood and understood by children the use of functional English like "Show and tell". Fun English learning activities (over English learning) was done this time, considering how enthusiastic the children in Taman Baca Kudi Dusun Cunil Pegalongan village Banyumas in every activity given. This English learning activity also aims to provide English introduction materials early so that they will be accustomed to facing all things related to the English language.
\end{abstract}

Article History:

Received: 13-10-2018

Revised : 27-12-2018

Accepted: 28-12-2018

Online : $30-12-2018$

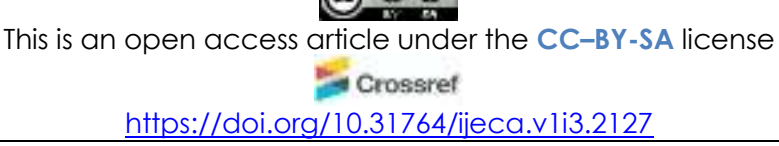

\section{A. INTRODUCTION}

Early childhood is a child who is at the age of 0-8 years. Early age is a golden age for children to learn the language, without neglecting the development of other aspects that are very important in life. Learning English in early childhood under 6 years is done as an introduction to language not as the main thing. According to Christina in Luhfiyah (Luthfiyah, 2016) that children aged 3-6 years most quickly understand English, if they are accustomed to express words or phrases in English.

English is an international language is very important even can be said to be mandatory especially in early childhood. Because with English speaking children will learn to communicate with others. In addition, by mastering English then the child will easily access the world of information and technology. With early English introduction, children will have better basic knowledge before continuing to higher education levels. 
Total Physical Response (TPR) is one method in language learning that makes language skills more quickly understood and understood by children, because teachers provide interesting lessons for children's sensory kinesthetic. And don't forget the teacher should always create a routine that is loaded with the use of functional English like "Show and tell". This method was developed by a Psychology Professor from the University San Jose California named James J. Asher. He assumed that the direct pronunciation of the child contained an order. Next the child will respond physically before they produce verbal or speech responses (Singh, 1970).

According to Tarigan in Inten (Intan dan nur dhihar, 2011) It should be noted that there are three main ideas, if a teacher wants to apply the TPR method in language learning, namely:

1. Understanding of spoken language must be developed by speaking

2. Understanding and memory are well obtained through body movements. Children answer or respond to commands

3. The teacher does not force the child to speak before they are ready because talking will appear naturally (Natural and behavioral).

Taman Baca Kudi is a learning place for children in Dusun Cunil, Pegalongan Village, Patikraja Subdistrict, Banyumas Regency started since March 07, 2015, with Sahabat Kudi with simple dream, can be useful for others. Together with the surrounding community, Taman Baca Kudi was built on the land owned by a citizen who invited to be used and the building also selfsupporting by the residents and support from Sahabat Kudi.

Taman Baca Kudi has always been active in various activities. Usually activities are done on Sunday or on national holidays. Local people are very enthusiastic about every activity held in Taman Baca Kudi. These activities include; learning to read, draw and color, play, storytelling, computer learning, and provide counseling about PHBS (Clean and Healthy Lifestyle) to younger siblings and the local community. English learning activities were once held in Taman Baca Kudi in 2015 and the children were very interested in learning English through songs. In addition to song, fun English learning can be done with games, watching movies or storytelling.

The game is one of the interesting activities in learning English. For teaching English, whether for small children or adults, the game can enliven the learning atmosphere. Plus, the game can make students want to continue learning English. Watching movies is one of the fastest ways to learn English. Through films in English, we not only learn grammar or grammar, but we also train our sense of hearing. Not only that, we also can practice to speak in English, as did the cast in the movie we watch.

Storytelling has many benefits. Among them are able to develop the power of thinking and imagination of children, storytelling is also influential in shaping the character of children before adulthood. In addition, from various ways to educate children, fairy tales are an effective way to provide human touch or human touch and sportsmanship for children. The child can also understand which things may be imitated and which ones should not be imitated.

Fun English learning activities (over English learning) above was done this time, considering how enthusiastic the children around Dusun Cunil Pegalongan village Banyumas in every activity given. This English learning activity also aims to provide English introduction materials early so that they will be accustomed to facing all things related to the English language. Based on the analysis of the situation, it can be identified partner problem that is Taman Baca Kudi is a place where the local people meet and gather to do various activities, especially activities devoted to children such as reading, storytelling, drawing and coloring. However, learning English activities are fun (fun English learning) is still rare they get. Not all children there are quite enthusiastic with English and they are sometimes lazy to learn it. 
Based on interviews to some children and observation, it is noticed that children have already done some activities dealing with English learning but they still get stuck in memorising vocabulary. From the problems that have been described, then some questions arise: How to raise children's interest in English? How to make children easy to remember English vocabulary? Some solutions will be implemented to solve the problems of partners, namely Fun learning activities in English (fun English learning) combining with Total Physical Response method.

The solution is to choose various activities that are fun for the child so as to maximize the activity of talking children, which is through songs, games, watching movies and storytelling combining with the use of TPR method. The purpose of these activities is used so that children improve understanding in English.

\section{B. METHODS}

This research is qualitative research (Arikunto, 2010). The methods used in conveying learning materials are lecture, question-answer, discussion and practice as well as practice using multimedia tools such as laptops, LCDs, printers and properties (whiteboards, drawings, cards). (Putri, 2016)

The activity was done in Taman Baca Kudi, a learning place for children in Dusun Cunil, Pegalongan Village, Patikraja Subdistrict, Banyumas Regency. The number of children who participated in this activity was 45 children with the age of about $7-10$ years. They are all children who become members in Taman Baca Kudi.

The children were divided into two groups. These two groups then were given two different methods of learning English. The purpose was to see which method was the most successful one for children to remember some new English words.

\section{RESULT AND DISCUSSION}

Learning vocabulary through games had been studied by several researchers. Donmus stated that "The value of educational games has been increasing in language education since they help to make language education entertaining ". According to Kuzu and Ural findings (Donmus, 2010) "when games and education are combined, it can be educative and education environments can be entertaining. The learners who learned with the use of games, gain positive attitudes and can be more motivated while learning".

Uberman (Derakhshan \& Davoodi Khatir, 2015) explained why game was needed in learning English. It is said that learning vocabulary is a hard work, so attempt is required to understand, produce and manipulate the target words. Games help and encourage many learners to learn target language more easily. They also help teachers to create contexts in which the target words are useful and meaningful; they also bring fun for students, thus help them learn and retain new words more quickly. In other words, game-based learning can create a meaningful context for language learning process. After learning and practicing new vocabulary through games, students have the opportunity to use language in a nonstressful way.

Games are advantageous and effective in learning vocabulary. They are motivating because they usually involve friendly competition and create cooperative learning environment, so students have an opportunity to work together. They improve students' communicative skills and they have a chance to use the target language (Azar, 2012).

Studies on Total Physical Response (TPR) method applied to teaching English vocabulary have been conducted. Some of them are first by Hsu and Lin (Lin, 2012) which aimed in investigating the effect of TPR on English functional vocabulary learning for resource classroom 
students. The study showed that students' motivation and interests in learning English were enhanced through TPR. Another research was carried out by Munoz (Munoz, 2011). The purpose of the research was to observe the impact caused by the usage of the TPR method. The results obtained reveal that teaching English vocabulary through physical response made children learn faster and easier, since children found support from the physical representation of their facilitator or their peers. Besides, a stress-free environment allowed children to be more receptive and motivated to the target language leaning.

The activities of Fun English Learning which combined with TPR method can be reported as follows: Children learnt English through fun learning activities with song, storytelling, games (games), watching movies and learning vocabulary through cards. Children memorized some basic English vocabulary and could apply it in everyday life. Games to improve children's English vocabulary. Games that were given were the theme of time and morning routines. Some pictures of the clock were given and participants were asked to write on the blackboard a number based on the picture of the watch. Participants were also given a number of random pictures showing the activities in the morning. Participants were asked to match the picture with the right sentence. Participants who could answer the questions in this game got a door prize.

In English song listening activities the theme was about time and morning routines. Participants listened to the song and the participants got some vocabulary related to the time:

\author{
What time is it now? What time is it? \\ Now it's 1 o'clock right It's 1 o'clock \\ Vocabulary related to the morning activities (morning routines) are: \\ Good morning! Good morning! \\ Wake up! It's time to wake up! \\ I wash my face I wash my face \\ I comb my hair I brush my hair \\ I dress I get dressed \\ I breakfast I eat my breakfast \\ I brushed my teeth brush my teeth \\ I wear shoes I put on my shoes.
}

After listening to the song, the participants joined in singing while memorizing the given vocabulary. Storytelling activities (story telling) was by reading the books fairy tale in English. Books of fairy tales that were given were stories about animal life with bilingual story that was the Story of Chickens and Eagles and Running Race. Participants read fairy tales in English first, trying to understand the contents of the story and then the participants read out the Indonesian language version.

Participants memorized some of the animal vocabulary in the story, among others: Rooster - Hen - Eagle - Rabbit -Tortoise - Snail - Ant - Fox. Watched a movie (watching movie) by playing an English-language movie with a short duration (5 to 10 minutes) and then recorded some vocabulary that was heard and practiced the vocabulary in a simple conversation. The short film that was playing was titled Push in Boots with a duration of 12 minutes. The movie is about a cat wearing very brave boots. Aided by their 3 kittens successfully paralyzed a villain named Whisper who had stolen the queen's jewelry. After watching this movie, participants discussed with some simple questions about the film. 
The activities were to demonstrate vocabulary related to "Things at Home" with flash cards (can be 2/3 times repetition). The teacher gave orders and models their actions and words while together with the children also did it. Children listened and demonstrated vocabulary.

Stimulus:

Teacher: Show me a pillow!

Teacher: This is a pillow

Children: This is a pillow.

The teacher gave orders to children together without giving a model.

Stimulus: Show me cupboard!

The teacher gave orders to children individually without giving a model. Children together answered the teacher's orders

Stimulus: Show me cupboard!

Children: This is cupboard.

The teacher gave a variation model to the child. The teacher brought a pitcher of water and pour it into a glass. Providing an explanation that we drink a water with the glass. Children listened and demonstrated the vocabulary.

Stimulus:

Take the pitcher!

Pour the water into the glass!

\section{CONCLUSION AND SUGGESTIONS}

Activities have been carried out with the Fun English Learning theme in Taman Baca Kudi Banyumas on April 16, 2018. This activity aims to provide an introduction to basic English for early childhood in there. Activities run smoothly. The participants followed the activity happily. They enthusiastically learned English and it is proved that by applying the TPR method, the participants could understand the instructions given in English.

To raise children's interest in learning English, some methods of teaching English were given, namely: Fun learning activities, including: listening to English song, storytelling, games, and watching movies. Before and after the activities, children were given a mini test focusing on Vocabulary about daily activities. The result showed that there was no significant changes about their vocabulary. They still cannot remember the words given. However, they enjoyed the activities a lot.

Teaching Vocabulary using TPR method: The activities were to demonstrate vocabulary related to "Things at Home" with flash cards (can be 2/3 times repetition). The teacher gave orders and models their actions and words while together with the children also did it. Children listened and demonstrated vocabulary.

The result showed that this method worked and children could easily remember the words given. In addition, they felt happy learning English using TPR Method. Suggestions for the future, in order to carry out similar activities but with different objects, namely English language activities intended for youth in Desa Cunil Banyumas.

\section{ACKNOWLEDGEMENT}

Thank you to University of AMIKOM Purwokerto and Taman Baca Kudi Banyumas which have contributed during the research. 


\section{REFERENCES}

Arikunto. (2010). Metodelogi Penelitian. Pendekatan Penelitian, 61-84.

Azar, A. S. (2012). The Effect of Games on EFL Learners' Vocabulary Learning Strategies. International Journal of Basic and Applied Science, 1(2), 238-242. https://doi.org/10.17142/ijbas-2012.1.2.10

Derakhshan, A., \& Davoodi Khatir, E. (2015). The Effects of Using Games on English Vocabulary Learning. Journal of Applied Linguistics and Language Research, 2(3), 39-47. www.jallr.ir

Donmus, V. (2010). The use of social networks in educational computer-game based foreign language learning. Procedia - Social and Behavioral Sciences, 9, 1497-1503. https://doi.org/10.1016/j.sbspro.2010.12.355

Intan dan nur dhihar. (2011). Penggunaan Metode Total Physical Response dalam Meningkatkan Kemampuan Menyimak dan Penguasaan Kosakata Bahasa Arab Anak Usia Dini Title.

Lin, hsu. (2012). No Title. The Effects Of Total Physical Response On English Functional Vocabulary Learning For Resource Classroom Students In The Elementary School (National Changhua University Of Education, Taiwan).

Luthfiyah, E. (2016). Pentingnya Bahasa Inggris Pada Anak Usia Dini. Retrieved September 3, 2018 from. http://erniluthfiyah.blogspot.co.id/2016/09/artikel-pentingnya-bahasainggris-pada.html.

Munoz, M. . (2011). Teaching English Vocabulary To Third Graders Through The Application Of The Total Physical Response Method. Thesis, Universidad Technologica De Pereire, 2011). Retrieved September 3, 2018. http://recursosbiblioteca.utp.edo.co/tesisdigitales/texto/4281M971.pdf

Putri, A. R. (2016). Teaching English for Young Learners Using a Total Physical Response (Tpr) Method. Jurnal Edulingua, 3(2), 16-20.

Singh, J. P. (1970). Effectiveness of Total Physical Response. Academic Voices: A Multidisciplinary Journal, 1, 20-22. https://doi.org/10.3126/av.v1i0.5303 